\title{
Chironomus plumosus larvae increase fluxes of denitrification products and diversity of nitrate-reducing bacteria in freshwater sediment
}

\author{
Morten Poulsen ${ }^{a}$, Michael V.W. Kofoed ${ }^{a}$, Lone H. Larsen ${ }^{a}$, Andreas Schrammª, \\ Peter Stief ${ }^{\mathrm{a}, \mathrm{b}, *}$ \\ a Department of Bioscience, Microbiology, Aarhus University, Ny Munkegade 114, 8000 Århus C, Denmark \\ b Max-Planck-Institute for Marine Microbiology, Microsensor Group, Celsiusstraße 1, 28359 Bremen, Germany
}

\section{A R T I C L E I N F O}

Article history:

Received 28 May 2013

Received in revised form 21 July 2013

Accepted 23 July 2013

\section{Keywords:}

Freshwater sediment

Macrofauna

Bioturbation

Gut bacteria

Denitrification

Nitrous oxide

Functional gene

Phylotype richness

\begin{abstract}
A B S T R A C T
Benthic invertebrates affect microbial processes and communities in freshwater sediment by enhancing sediment-water solute fluxes and by grazing on bacteria. Using microcosms, the effects of larvae of the widespread midge Chironomus plumosus on the efflux of denitrification products $\left(\mathrm{N}_{2} \mathrm{O}\right.$ and $\left.\mathrm{N}_{2}+\mathrm{N}_{2} \mathrm{O}\right)$ and the diversity and abundance of nitrate- and nitrous-oxide-reducing bacteria were investigated. Additionally, the diversity of actively nitrate- and nitrous-oxide-reducing bacteria was analyzed in the larval gut. The presence of larvae increased the total effluxes of $\mathrm{N}_{2} \mathrm{O}$ and $\mathrm{N}_{2}+\mathrm{N}_{2} \mathrm{O}$ up to 8.6- and 4.2-fold, respectively, which was mostly due to stimulation of sedimentary denitrification; incomplete denitrification in the guts accounted for up to $20 \%$ of the $\mathrm{N}_{2} \mathrm{O}$ efflux. Phylotype richness of the nitrate reductase gene narG was significantly higher in sediment with than without larvae. In the gut, 47 narG phylotypes were found expressed, which may contribute to higher phylotype richness in colonized sediment. In contrast, phylotype richness of the nitrous oxide reductase gene nos $Z$ was unaffected by the presence of larvae and very few nos $Z$ phylotypes were expressed in the gut. Gene abundance of neither narG, nor nos $Z$ was different in sediments with and without larvae. Hence, $C$. plumosus increases activity and diversity, but not overall abundance of nitrate-reducing bacteria, probably by providing additional ecological niches in its burrow and gut.
\end{abstract}

(c) 2013 Published by Elsevier GmbH.

\section{Introduction}

Benthic invertebrates influence the reaction rates of microbial and geochemical processes and the abundance and distribution of microbes in sediments [1,26,32]. Particle reworking through bioturbation activity and ventilation of tubular burrows by the invertebrates strongly enhance the solute exchange between sediment and water compared to molecular diffusion across the bare sediment-water interface $[1,26,39]$. Consequently, transport of substrates and products of microbial and geochemical processes is more efficient, which increases reaction rates in the sediment. Additionally, benthic invertebrates excrete spinning silk, mucus, feces, and ammonium and thereby enrich the burrows with organic matter and nutrients $[15,28,48]$, which makes them preferred colonization sites for bacteria $[29,33]$.

Benthic invertebrates also directly influence bacterial abundance in sediments by their grazing activity. Deposit-feeding chironomid larvae significantly decrease bacterial abundance at the

\footnotetext{
* Corresponding author at: NordCEE, Institute of Biology, University of Southern Denmark, Campusvej 55, 5230 Odense M, Denmark. Tel.: +45 65502724.

E-mail address: peterstief@biology.sdu.dk (P.Stief).
}

sediment surface $[2,20]$ and change the bacterial community structure by selective grazing [58]. Not all of the ingested bacteria are digested in the invertebrate gut $[20,36]$, but the effect of differential survival on microbial community structure in the sediment is not generally known; it might be minor because recolonization of feces occurs through immigration of bacteria from ambient sediment rather than through regrowth of survivors [37].

An inverse effect of grazing on microbial communities in sediments occurs when ingested bacteria do not only survive the gut passage, but also remain or even become metabolically active in the gut. Certain metabolic pathways may be induced by the shift in microenvironmental conditions from water or sediment surface to invertebrate gut. In the gut of Chironomus plumosus larvae (Insecta, Diptera), for instance, low $\mathrm{O}_{2}$ and high $\mathrm{NO}_{3}{ }^{-}$concentrations prevail $[47,50]$. As a consequence, denitrification activity is induced in some of the ingested bacteria that are normally exposed to $\mathrm{O}_{2}$ in the water column or at the sediment surface [49]. Denitrification is the dissimilatory reduction of nitrate $\left(\mathrm{NO}_{3}{ }^{-}\right)$either completely to dinitrogen $\left(\mathrm{N}_{2}\right)$ or to nitrous oxide $\left(\mathrm{N}_{2} \mathrm{O}\right)$ only, when the last reduction step is absent, repressed or running at a lower rate than the preceeding reduction steps [59]. Strikingly, the $\mathrm{N}_{2} \mathrm{O}$ yield of gut denitrification is much higher than that of sedimentary denitrification [49], probably because of delayed induction of the nitrous 
oxide reductase gene after the oxic-anoxic shift $[4,12,19]$. The feces of $C$. plumosus larvae might therefore be rich in surviving denitrifiers with all reductase genes expressed, except for maybe the nitrous oxide reductase gene. In addition to denitrifiers, bacteria capable of dissimilatory nitrate reduction to ammonium (DNRA) may find suitable conditions in the invertebrate gut and their genes may also be expressed during the gut passage. The same accounts for bacteria that reduce $\mathrm{NO}_{3}{ }^{-}$to nitrite $\left(\mathrm{NO}_{2}{ }^{-}\right)$and not further (e.g., many fermenters, enteric bacteria, or Bacillus species). Since the feces excreted by $C$. plumosus may serve as microbial inocula to the ambient sediment, the larval grazing activity may eventually promote bacteria mediating dissimilatory nitrate reduction pathways and increase their abundance in the sediment.

The present study focused on the direct and indirect effects of C. plumosus larvae on nitrate reduction, incomplete denitrification to $\mathrm{N}_{2} \mathrm{O}$, and complete denitrification to $\mathrm{N}_{2}$ in freshwater sediment. C. plumosus larvae are common and abundant in lake sediments where they construct U-shaped burrows which they periodically ventilate [40]. The diet of the larvae consists of organic particles and the attached bacteria and microalgae that are acquired by depositand filter-feeding [57]. Two hypotheses were tested:(1) C. plumosus larvae increase the sediment-water flux of denitrification products $\left(\mathrm{N}_{2} \mathrm{O}\right.$ and $\left.\mathrm{N}_{2}+\mathrm{N}_{2} \mathrm{O}\right)$, and (2) C. plumosus larvae increase abundance and diversity of nitrate- and nitrous-oxide-reducing bacteria in the sediment. Our objectives were to (1) quantify the direct larval emissions and the indirect larval stimulation of sedimentary emissions at different larval densities, and (2) to quantify abundance and diversity of the genes encoding the nitrate reductase (narG) and the nitrous oxide reductase (nosZ) in sediments with and without larvae. To test for direct effects of $C$. plumosus larvae on nitrateand nitrous-oxide-reducing bacteria, the diversity of narG and nos $Z$ transcripts was analyzed in the larval gut content. The differential appearance of individual narG and nosZ phylotypes in three gene libraries (i.e., sediment with and without larvae, gut content) was used to identify the mechanisms behind the $C$. plumosus effects on nitrate- and nitrous-oxide-reducing bacteria.

\section{Materials and methods}

\section{Sedimentary and larval emission of denitrification products}

Sediment was collected in Lake Großer Binnensee (Northern Germany, $54^{\circ} 19^{\prime} 40^{\prime \prime} \mathrm{N}, 10^{\circ} 37^{\prime} 30^{\prime \prime} \mathrm{E}$ ). After defaunation by sieving, sediment was filled into 24120 -mL glass bottles that were left open and submersed in four 10 - $\mathrm{L}$ tanks containing $\mathrm{NO}_{3}{ }^{-}$-enriched tap water $\left(500 \mu \mathrm{mol} \mathrm{L}^{-1}\right)$. Each bottle was flushed with air through a hypodermic needle positioned in the bottleneck. The air bubbles escaping from the bottles also provided for a continuous exchange of water between the tank and the bottles. After a two-week equilibration period, the sediments were spiked with 0,2 , 4 , or 6 fourth-instar $C$. plumosus larvae from Lake Großer Binnensee per bottle (six replicates each), which corresponded to $0,1150,2300$, or 3450 individuals per $\mathrm{m}^{2}$, respectively. After an incubation period of one week, the bottles were retrieved from the tanks and the total efflux of denitrification products $\left(\mathrm{N}_{2} \mathrm{O}\right.$ and $\left.\mathrm{N}_{2}+\mathrm{N}_{2} \mathrm{O}\right)$ was determined in each bottle according to [51]. Briefly, the bottles were sealed with a rubber septum leaving a $5-\mathrm{mL}$ air-filled headspace in the bottleneck. The accumulation of $\mathrm{N}_{2} \mathrm{O}$ in the headspace was monitored for $3-5 \mathrm{~h}$ by gas chromatography and used to calculate the total $\mathrm{N}_{2} \mathrm{O}$ efflux (i.e., the total $\mathrm{N}_{2} \mathrm{O}$ flux out of the sediment into the overlying water) as a measure of incomplete denitrification. Additional incubations without $\mathrm{NO}_{3}{ }^{-}$added to the water column revealed that the $\mathrm{N}_{2} \mathrm{O}$ efflux due to nitrification, the sequential oxidation of $\mathrm{NH}_{4}{ }^{+}$via $\mathrm{NO}_{2}{ }^{-}$to $\mathrm{NO}_{3}{ }^{-}$, was negligible (data not shown). The bottles were incubated a second time with the overlying water adjusted to $10 \%$ saturation of acetylene to inhibit the last step of denitrification [44]. In this case, the accumulation of $\mathrm{N}_{2} \mathrm{O}$ in the headspace was used to calculate the total $\mathrm{N}_{2}+\mathrm{N}_{2} \mathrm{O}$ efflux as a measure of complete denitrification.

The direct emission of $\mathrm{N}_{2} \mathrm{O}$ and $\mathrm{N}_{2}+\mathrm{N}_{2} \mathrm{O}$ by C. plumosus larvae was quantified according to [49]. Briefly, larvae were collected from the sediment and individually incubated in air-filled, gas-tight vials $(3 \mathrm{~mL})$. The accumulation of $\mathrm{N}_{2} \mathrm{O}$ in the vials was monitored for $4-5 \mathrm{~h}$ by gas chromatography and used to calculate the individual $\mathrm{N}_{2} \mathrm{O}$ emission rate of the larvae. A second batch of larvae was incubated in an atmosphere of $10 \%$ acetylene and $90 \%$ air. In this case, the accumulation of $\mathrm{N}_{2} \mathrm{O}$ in the vials was used to calculate the individual $\mathrm{N}_{2}+\mathrm{N}_{2} \mathrm{O}$ emission rate of the larvae.

\section{Sampling for analysis of nitrate- and nitrous-oxide-reducing bacteria}

Defaunated lake sediment was homogenized and filled into six 300-mL glass beakers that were submersed into two 10-L tanks containing $\mathrm{NO}_{3}{ }^{-}$-enriched tap water $\left(500 \mu \mathrm{mol} \mathrm{L}^{-1}\right)$. Mixing of water within the tanks was achieved by aeration using an air pump and a diffusor. After a two-week equilibration period, three beakers were each spiked with six fourth-instar C. plumosus larvae (which corresponded to 1333 individuals per $\mathrm{m}^{2}$ ), while the other three beakers served as controls. After an incubation period of two weeks, the beakers were retrieved from the tanks and in each beaker the upper $8 \mathrm{~mm}$ of the sediment, which covered both the oxic sediment layer and the anoxic nitrate-reducing layer, was sampled with a sterile core liner. The remaining sediment was searched through to retrieve the living larvae. Both sediment samples and larvae were immediately frozen at $-80^{\circ} \mathrm{C}$.

\section{DNA and RNA extraction}

DNA was extracted in triplicates from the sediment samples by combined enzymatic and mechanical lysis as described previously [13]. DNA concentrations were determined using Picogreen (Invitrogen, USA) on a Nanodrop fluorometer (Thermo-Scientific, USA) [25]. RNA was extracted from the gut contents of dissected C. plumosus using the FastRNA ${ }^{\circledR}$ Pro Soil-Direct Kit (Qbiogene Inc., California, USA). RNA extracts tested negatively for residual DNA by 165 rRNA gene-targeted PCR [19]. cDNA was generated from RNA extracts with random hexamer primers using the iScript cDNA Synthesis Kit (Biorad, California, USA).

\section{Diversity of narG and nosZ}

Gene fragments of narG (690 bp) and nosZ (700 bp) were amplified, cloned, sequenced, and phylogenetically analyzed as previously described [49]. To broaden primer coverage for nosZ, a second fragment (1100 bp) was amplified following the protocol of [41], but using four annealing temperatures in parallel $(51.2,53$, 55.2 , and $57^{\circ} \mathrm{C}$ ). The resulting PCR products were pooled, cloned, sequenced, and added to the phylogenetic analysis described above. Nine clone libraries were analyzed at nucleic acid level: 3 samples $\left(\mathrm{S}_{0}\right.$ : sediment without larvae, $\mathrm{S}_{1}$ : sediment with larvae, $\mathrm{G}$ : gut contents $) \times 3$ gene fragments $(1 \times$ narG, $2 \times$ nos $Z)$. Sequences were assigned to phylotypes in DOTUR [42] using 97, 90, and 80\% sequence identity cut-off values. Phylotype richness of each clone library was estimated using the software package compiled by [23]. One sequence of each phylotype was deposited in GenBank (accession no. EU052803 to EU053075).

The appearance of individual narG and nosZ phylotypes in the libraries for the three samples was listed in a presence/absence matrix. Individual phylotypes could appear either in one, two, or three libraries. Thus, seven different categories of phylotype 
distribution between the samples were possible: $S_{0}, S_{1}, G, S_{0}+S_{1}$, $S_{0}+G, S_{1}+G$, and $S_{0}+S_{1}+G$. The relative frequency of each category was determined for each gene analyzed. To this end, all nosZ phylotypes were combined because the two primer pairs retrieved non-overlapping sets of phylotypes. The evaluation was repeated at 97,90 , and $80 \%$ sequence identity cut-off values.

\section{Abundance of narG and nosZ genes}

Gene copy numbers of narG were quantified by qPCR with primers narG1960F and narG2008R as previously described [25]. For qPCR targeting nosZ, primers nosZ1181F_b (5'-GNT GTT CMT CGA CAG YCA R-3') and nosZ1382R (5'-ARC GRT CYT TSG AGA AYT TG-3') were designed based on nos $Z$ sequences obtained in this study using the ARB software package [30]. A $20 \mu \mathrm{L}$ reaction mix contained $10 \mu \mathrm{L}$ LC-FastStart DNA Master SYBR ${ }^{\circledR}$ Green I Master mix (Roche), $1 \mu \mathrm{L}$ template DNA (diluted $1: 10$ ), $0.5 \mathrm{mg} \mathrm{mL}^{-1}$ bovine serum albumin, and $0.5 \mu \mathrm{mol} \mathrm{L}^{-1}$ of each primer. Three independent serial dilutions $\left(10^{8}\right.$ to $10^{3}$ gene copies $\left.\mu \mathrm{L}^{-1}\right)$ of a nosZ-containing plasmid (EU053038) served as standards. Thermal cycling on a LC480 Lightcycler (Roche) was as follows: $300 \mathrm{~s}$ enzyme activation at $95^{\circ} \mathrm{C}$; then cycles of denaturation $\left(95^{\circ} \mathrm{C}\right), 30 \mathrm{~s}$; annealing $\left(59^{\circ} \mathrm{C}\right), 30 \mathrm{~s}$; extension $\left(72^{\circ} \mathrm{C}\right), 30 \mathrm{~s}$; and data acquisition $\left(80^{\circ} \mathrm{C}\right)$. Amplification efficiency of the new qPCR assay was $66.2 \%\left(r^{2}=0.988\right)$, specificity was confirmed by detection of the desired $201 \mathrm{bp-qPCR}$ product by agarose gel electrophoresis and by cloning and sequencing of the PCR product, which revealed exclusively nosZ among 20 randomly picked clones.

Gene copy numbers of narG and nosZ were quantified in triplicate in three independent DNA extracts from sediment with and without $C$. plumosus, normalized for DNA concentrations, and differences in gene abundance between sediment with and without C. plumosus were evaluated using Student's $t$ test.

\section{Results and discussion}

\section{Sedimentary and larval emission of denitrification products}

The total $\mathrm{N}_{2} \mathrm{O}$ efflux from the sediment microcosms increased linearly with C. plumosus density (Fig. $1(A)$ ). Direct larval $\mathrm{N}_{2} \mathrm{O}$ emission due to incomplete denitrification in the gut [49] contributed $15.4,19.2$, and $19.4 \%$ to this increase at larval densities of 1150,2300 , and 3450 individuals per $\mathrm{m}^{2}$, respectively (Fig. 1(A)). Thus, while most of the increase in total $\mathrm{N}_{2} \mathrm{O}$ efflux was due to stimulation of sedimentary $\mathrm{N}_{2} \mathrm{O}$ emission, the direct contribution by the larvae was still substantial. The total $\mathrm{N}_{2}+\mathrm{N}_{2} \mathrm{O}$ efflux also increased with larval density in the sediment, but leveled off at a density higher than 2300 individuals per $\mathrm{m}^{2}$ (Fig. 1(B)). The contribution of direct $\mathrm{N}_{2}+\mathrm{N}_{2} \mathrm{O}$ emission by $C$. plumosus larvae to the total $\mathrm{N}_{2}+\mathrm{N}_{2} \mathrm{O}$ efflux was negligible (Fig. 1(B), inset). Maximally, the total effluxes of $\mathrm{N}_{2} \mathrm{O}$ and $\mathrm{N}_{2}+\mathrm{N}_{2} \mathrm{O}$ increased 8.6- and 4.2-fold, respectively, relative to the background fluxes in the absence of larvae.

The stimulation of sedimentary $\mathrm{N}_{2} \mathrm{O}$ and $\mathrm{N}_{2}+\mathrm{N}_{2} \mathrm{O}$ emission probably takes effect directly in the larval burrows from which the gases are efficiently transported into the water column due to the periodic ventilation activity of the larvae [35,53]. Chironomid burrows are distinct microsites in the sediment enriched with particulate organic matter $[27,48]$ and show pronounced fluctuations of $\mathrm{O}_{2}$ and $\mathrm{NO}_{3}{ }^{-}$concentrations [38,46,49]. Hence, denitrification activity and concomitant $\mathrm{N}_{2} \mathrm{O}$ production may prevail during the anoxic phase [50], whereas nitrification activity with $\mathrm{N}_{2} \mathrm{O}$ as a byproduct of ammonia oxidation [7] may prevail during the oxic

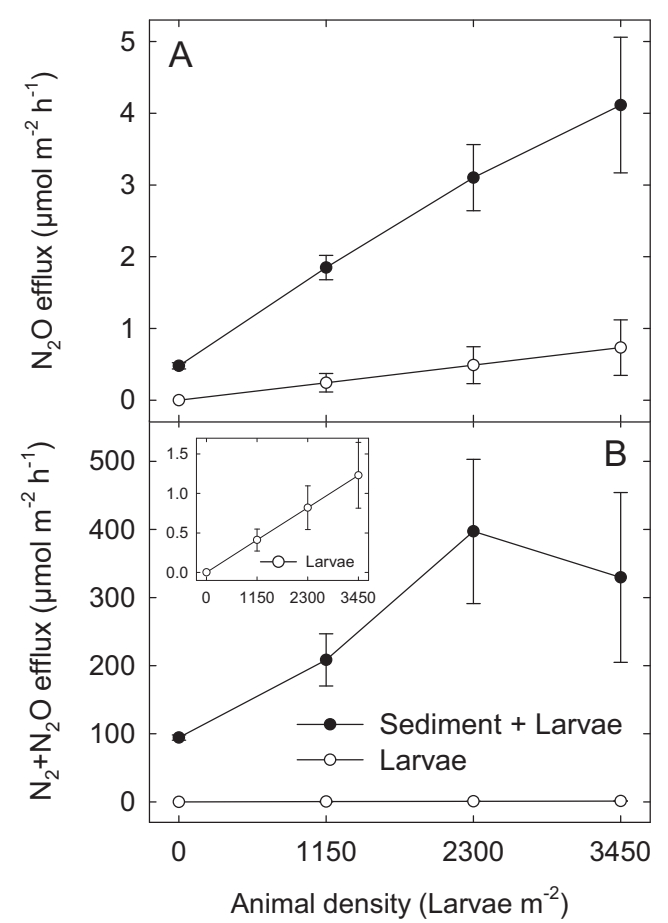

Fig. 1. Total efflux of (A) $\mathrm{N}_{2} \mathrm{O}$ and (B) $\mathrm{N}_{2}+\mathrm{N}_{2} \mathrm{O}$ from lake sediment measured at different densities of $C$. plumosus larvae $(\bullet)$ and extrapolated from rates of direct larval emissions $(\bigcirc)$. Direct larval $\mathrm{N}_{2} \mathrm{O}$ emission contributed approximately $15-20 \%$ to the total $\mathrm{N}_{2} \mathrm{O}$ efflux, while direct larval $\mathrm{N}_{2}+\mathrm{N}_{2} \mathrm{O}$ emission (highlighted in inset)did not significantly contribute to the total $\mathrm{N}_{2}+\mathrm{N}_{2} \mathrm{O}$ efflux. Error bars indicate standard error of the mean $(n=6)$.

phase. In fact, the stimulation of nitrification and total efflux of $\mathrm{N}_{2} \mathrm{O}$ by $C$. plumosus were correlated in a lake sediment studied by [54]. In the lake sediment used here, however, denitrification was likely the main source of $\mathrm{N}_{2} \mathrm{O}$, since in control microcosms without $\mathrm{NO}_{3}{ }^{-}$ addition, $\mathrm{N}_{2} \mathrm{O}$ emission was negligible (data not shown).

The $\mathrm{N}_{2} \mathrm{O}$ yield of both nitrification and denitrification generally reaches high values under hypoxic [10] and fluctuating $\mathrm{O}_{2}$ conditions $[24,43]$. Accordingly, the ratio of total $\mathrm{N}_{2} \mathrm{O}$ to total $\mathrm{N}_{2}+\mathrm{N}_{2} \mathrm{O}$ emissions increased from $0.5 \%$ in microcosms without burrows to $1.2 \%$ in microcosms with the highest density of periodically ventilated burrows (calculated from data in Fig. 1). The larvae also contribute directly to this increase by the extremely high $\mathrm{N}_{2} \mathrm{O}$ yield of denitrification in their guts (15-68\%) [49]. Unlike in the burrows, $\mathrm{O}_{2}$ is largely absent from the gut contents of $C$. plumosus larvae [47]. The high $\mathrm{N}_{2} \mathrm{O}$ yield is therefore not explained by hypoxic or fluctuating $\mathrm{O}_{2}$ conditions in the gut, but rather by delayed induction of the nitrous oxide reductase in the gut contents [19,49]. Additionally, the high ratio of total $\mathrm{N}_{2} \mathrm{O}$ to total $\mathrm{N}_{2}+\mathrm{N}_{2} \mathrm{O}$ emissions at the highest larval density is explained by the absence of a further increase in the total $\mathrm{N}_{2}+\mathrm{N}_{2} \mathrm{O}$ emission (Fig. 1(B)). At very high animal density, the sediment between burrows is increasingly oxygenated, which eventually inhibits denitrification in the burrow layer [14].

Density-dependent increases in the total efflux of denitrification products $\left(\mathrm{N}_{2}+\mathrm{N}_{2} \mathrm{O}\right)$ have been observed for a number of marine and freshwater invertebrates $[3,11,34,51,52,55]$. The main mechanism of increased sedimentary denitrification is the efficient transport of $\mathrm{NO}_{3}{ }^{-}$from the water column to deep, anoxic sediment layers by the periodic ventilation activity of the animals. Little is known about the concomitant increase in total efflux of $\mathrm{N}_{2} \mathrm{O}$ from bioturbated sediments. Aside from C. plumosus [49,50,54], only two more sediment-dwelling freshwater species have been studied, the mayfly Ephemera danica and the alderfly Sialis lutaris [51]. C. plumosus and E. danica larvae contribute to the total $\mathrm{N}_{2} \mathrm{O}$ efflux by 
Table 1

Abundance of the narG and nos $Z$ genes in sediment samples.

\begin{tabular}{|c|c|c|c|}
\hline & Sediment without C. plumosus & Sediment with C. plumosus & $P$-value \\
\hline narG copies per ng DNA & $1.9 \times 10^{6}\left( \pm 0.8 \times 10^{6}\right)$ & $2.4 \times 10^{6}\left( \pm 1.1 \times 10^{6}\right)$ & 0.726 \\
\hline nos $Z$ copies per ng DNA & $4.1 \times 10^{5}\left( \pm 1.6 \times 10^{5}\right)$ & $4.1 \times 10^{5}\left( \pm 1.9 \times 10^{5}\right)$ & 0.498 \\
\hline
\end{tabular}

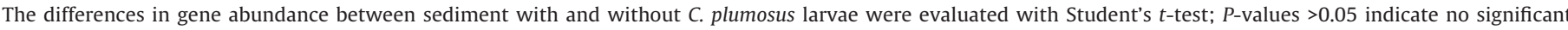
difference between the two samples. Mean values (standard deviation) of three replicates are given.

Table 2

Clone libraries of the narG and nosZ genes in sediment and gut samples.

\begin{tabular}{|c|c|c|c|c|c|}
\hline Gene fragment & Sample & No. of clones screened & No. of phylotypes observed & Coverage (\%)* & $\begin{array}{l}\text { Estimated no. of phylotypes } \\
\text { by Chao } 1^{* *}\end{array}$ \\
\hline \multirow[t]{3}{*}{ narG } & Sediment without C. plumosus & 79 & 40 & 71 & 68 \\
\hline & Sediment with C. plumosus & 102 & 68 & 49 & 170 \\
\hline & Gut content of $C$. plumosus & 109 & 25 & 86 & 47 \\
\hline \multirow[t]{3}{*}{$\operatorname{nos} Z(1100 \mathrm{bp})$} & Sediment without $C$. plumosus & 53 & 10 & 98 & 10 \\
\hline & Sediment with C. plumosus & 53 & 7 & 98 & 7 \\
\hline & Gut content of $C$. plumosus & 33 & 1 & 100 & n.a. \\
\hline \multirow[t]{3}{*}{$\operatorname{nosZ}(700 \mathrm{bp})$} & Sediment without $C$. plumosus & 99 & 14 & 92 & 21 \\
\hline & Sediment with C. plumosus & 82 & 16 & 90 & 22 \\
\hline & Gut content of $C$. plumosus & 16 & 7 & 75 & 10 \\
\hline
\end{tabular}

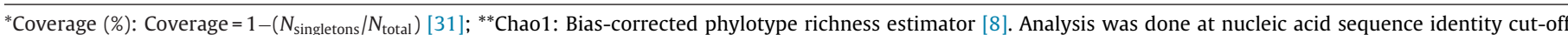

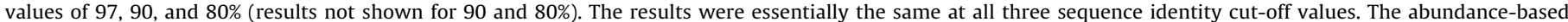
coverage estimator (ACE) by [9] showed similar results as the Chao1-model (results not shown).

gut denitrification and by stimulating sedimentary denitrification, while S. lutaria only stimulates sedimentary denitrification. More recently, also mussels and snails living on top of freshwater and marine sediments were found to emit $\mathrm{N}_{2} \mathrm{O}[16,17,52]$. The invasive freshwater mussel Dreissena polymorpha emits $\mathrm{N}_{2} \mathrm{O}$ produced by nitrification in the biofilm growing on its shell and by denitrification in its gut. Apparently, this type of dual $\mathrm{N}_{2} \mathrm{O}$ emission is also widespread in coastal marine mussels and snails [16,17].

\section{Abundance and diversity of nitrate- and nitrous-oxide-reducing bacteria}

The higher $\mathrm{N}_{2} \mathrm{O}$ and $\mathrm{N}_{2}+\mathrm{N}_{2} \mathrm{O}$ fluxes in sediments inhabited by $C$. plumosus may be explained by an increase in abundance and/or cell-specific activity of nitrate-reducing and denitrifying bacteria through bioturbation, ventilation, and grazing activities of the larvae. Gene copy numbers of narG and nosZ were not

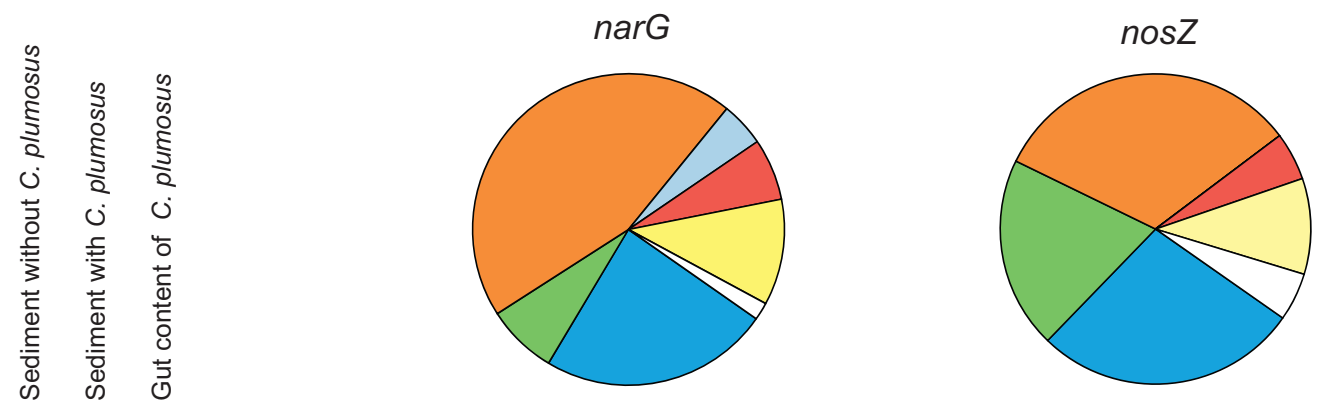

Phylotypes were eliminated through removal of ecological niches in the sediment and/or through digestion by $C$. plumosus

Phylotypes were neither metabolically induced in the C. plumosus gut, nor eliminated from the sediment by C. plumosus

Phylotypes were promoted through provision of additional ecological niches in the sediment by C. plumosus

Phylotypes were promoted through metabolic induction in the C. plumosus gut, followed by inoculation of the sediment

Phylotypes were metabolically induced in the C. plumosus gut, but not affected in the sediment

Phylotypes were metabolically induced in the C. plumosus gut, but were not abundant in the sediment

Phylotypes were metabolically induced in the C. plumosus gut, but eliminated from the sediment by C. plumosus

Fig. 2. Pie charts: Relative frequency of appearance of narG and nosZ phylotypes in clone libraries constructed for sediment with and without C. plumosus (DNA) and the gut content of $C$. plumosus (RNA). The total number (i.e., 100\%) of narG and nosZ phylotypes in the three clone libraries was 114 and 42 , respectively. The three libraries are represented as vertical columns; the seven possible categories of phylotype appearance in the libraries are represented as rows of one or more colored boxes. Each category represents one or more putative mechanisms of $C$. plumosus effects on the nitrate reducer and/or denitrifying community in the sediment. For example, narG phylotypes, exclusively detected in sediment with larvae are represented by the color orange, were likely promoted through niche construction by $C$. plumosus, and made up $45 \%$ of all narG phylotypes observed. This evaluation gave identical results at sequence identity cut-off values of $97 \%, 90 \%$, and $80 \%$ (results not shown for $90 \%$ and $80 \%$ ). 
significantly different between inhabited and non-inhabited sediment (Table 1). Increases in total abundance of nitrate-reducing and denitrifying bacteria are thus not supported by these data, while abundance changes of individual narG and nosZ phylotypes cannot be ruled out. Such phylotype-specific changes in abundance can influence the $\mathrm{N}_{2} \mathrm{O}$ and $\mathrm{N}_{2}+\mathrm{N}_{2} \mathrm{O}$ fluxes, if these phylotypes have particularly high or low metabolic activities [5,6]. A combination of higher cell-specific rates and changes in the community composition may thus explain the increased $\mathrm{N}_{2} \mathrm{O}$ and $\mathrm{N}_{2}+\mathrm{N}_{2} \mathrm{O}$ fluxes.

The community composition of nitrate- and nitrous-oxidereducing bacteria was indeed affected by the presence of $C$. plumosus larvae: estimated phylotype richness of the narG gene was higher in sediment with larvae (170 phylotypes) compared to sediment without larvae (68 phylotypes) (Table 2$)$. The additional narG phylotypes in sediment with larvae covered a broad

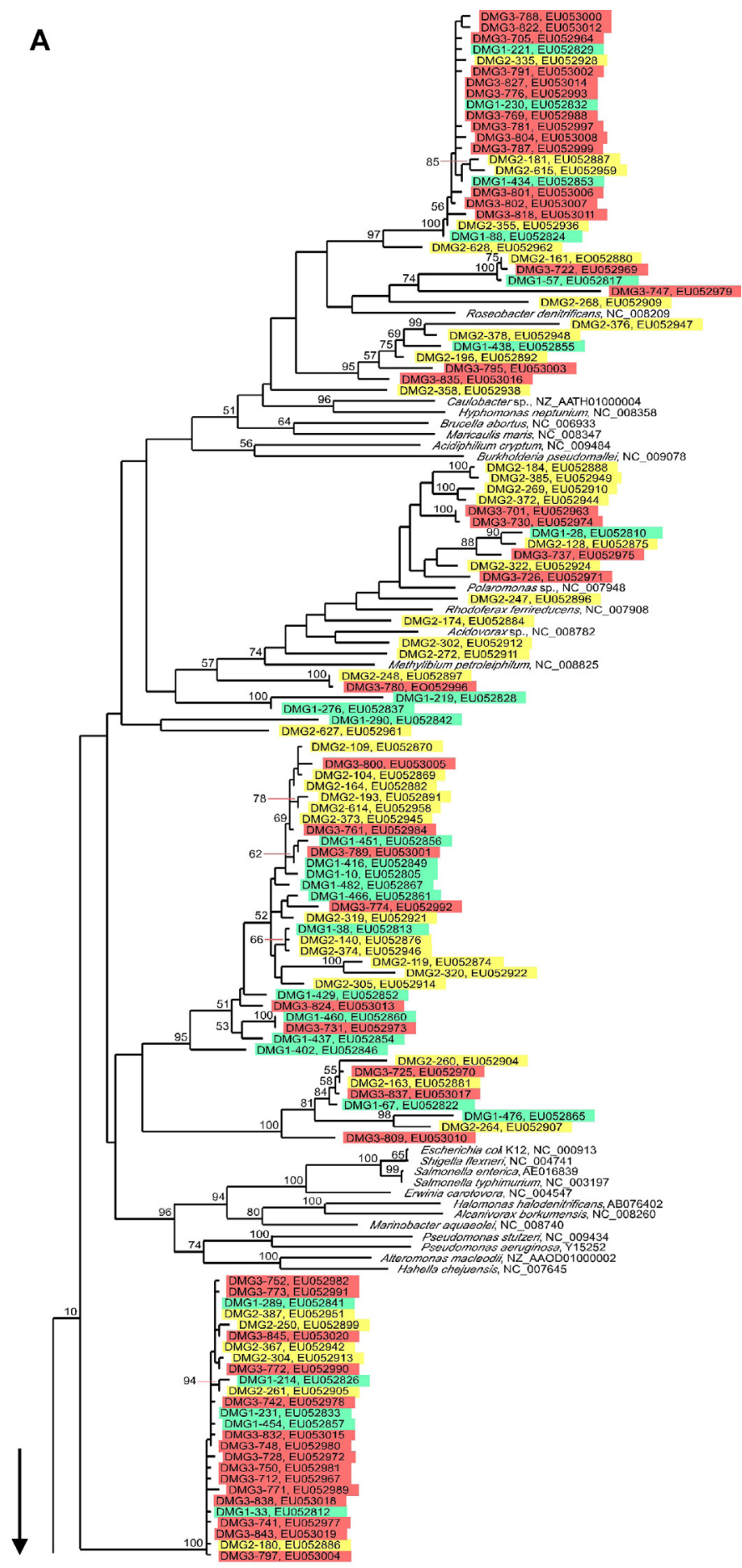

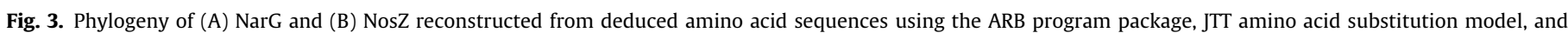

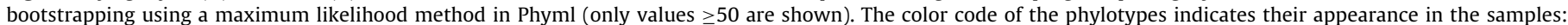

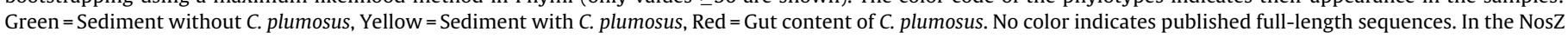
tree, the letters $\mathrm{a}$ and $\mathrm{b}$ in the clone names denote $1100 \mathrm{bp}$ and $700 \mathrm{bp}$ phylotypes, respectively. 
taxonomic spectrum (Fig. 3(A)). In contrast, the estimated phylotype richness of the nos $Z$ gene was highly similar in sediment with larvae (29 phylotypes) and without larvae ( 31 phylotypes) (Table 2). Nevertheless, there was little overlap between phylotypes of the two communities, indicating a change in community composition also for nosZ-containing denitrifiers (Fig. 3(B)). The nos $Z$ phylotypes in sediment with and without larvae covered a relatively broad taxonomic spectrum but more narrow than for narG (Fig. 3(B)). The generally lower nosZ abundance and phylotype richness compared to narG can be explained by the fact that nitrate reducers usually outnumber denitrifiers in terrestrial and aquatic environments $[18,19,45,56]$, and that even of true denitrifiers about $30 \%$ do not carry a nitrous oxide reductase [21,59]. It should also be noted that the primer sets used for nosZ here (as in most other studies) do not target Gram-positive nitrous-oxide reducers [22]; their importance for freshwater sediment is as yet unknown. Additionally, the estimated phylotype richness of narG and nos $Z$ transcripts in the gut was 47 and 10, respectively (Table 2); the observed narG and nosZ phylotypes covered a broad taxonomic spectrum (Fig. 3(A) and (B)).

Clone-based sequencing approaches may bias the analysis of microbial community composition due to limited sampling depth. Next-generation sequencing allows to produce 2-3 orders of magnitude more sequences from any given sample than clone-based sequencing and thereby to overcome bias due to undersampling. In the narG and nos $Z$ clone libraries, significant undersampling was evident for narG in sediment with and without $C$. plumosus larvae (49 and 71\% coverage, respectively) and for nos $Z$ transcripts in the gut of the larvae (75\% coverage) (Table 2 ). It can thus be expected that a larger sequencing effort would have revealed an even greater

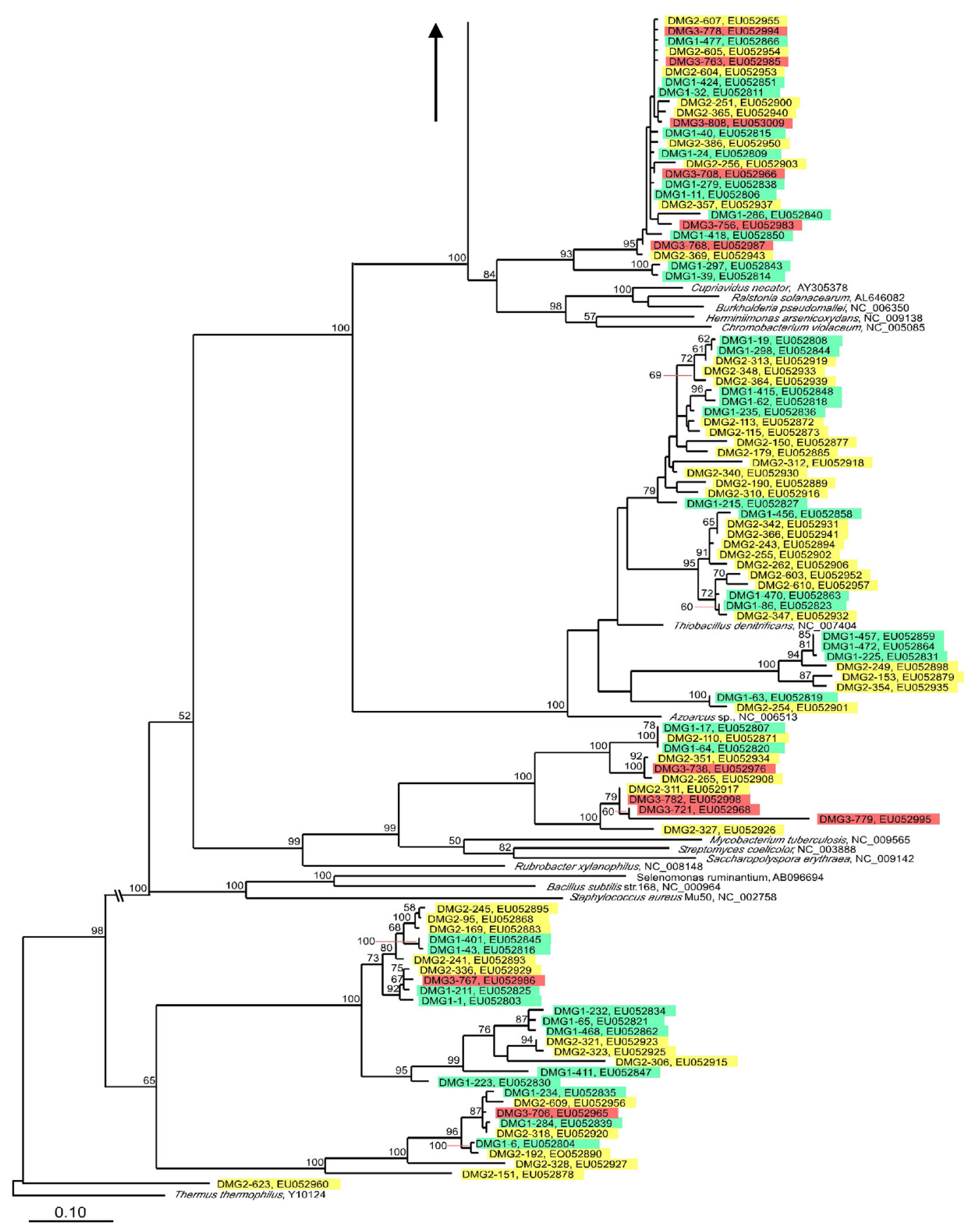

Fig. 3. (Continued) 


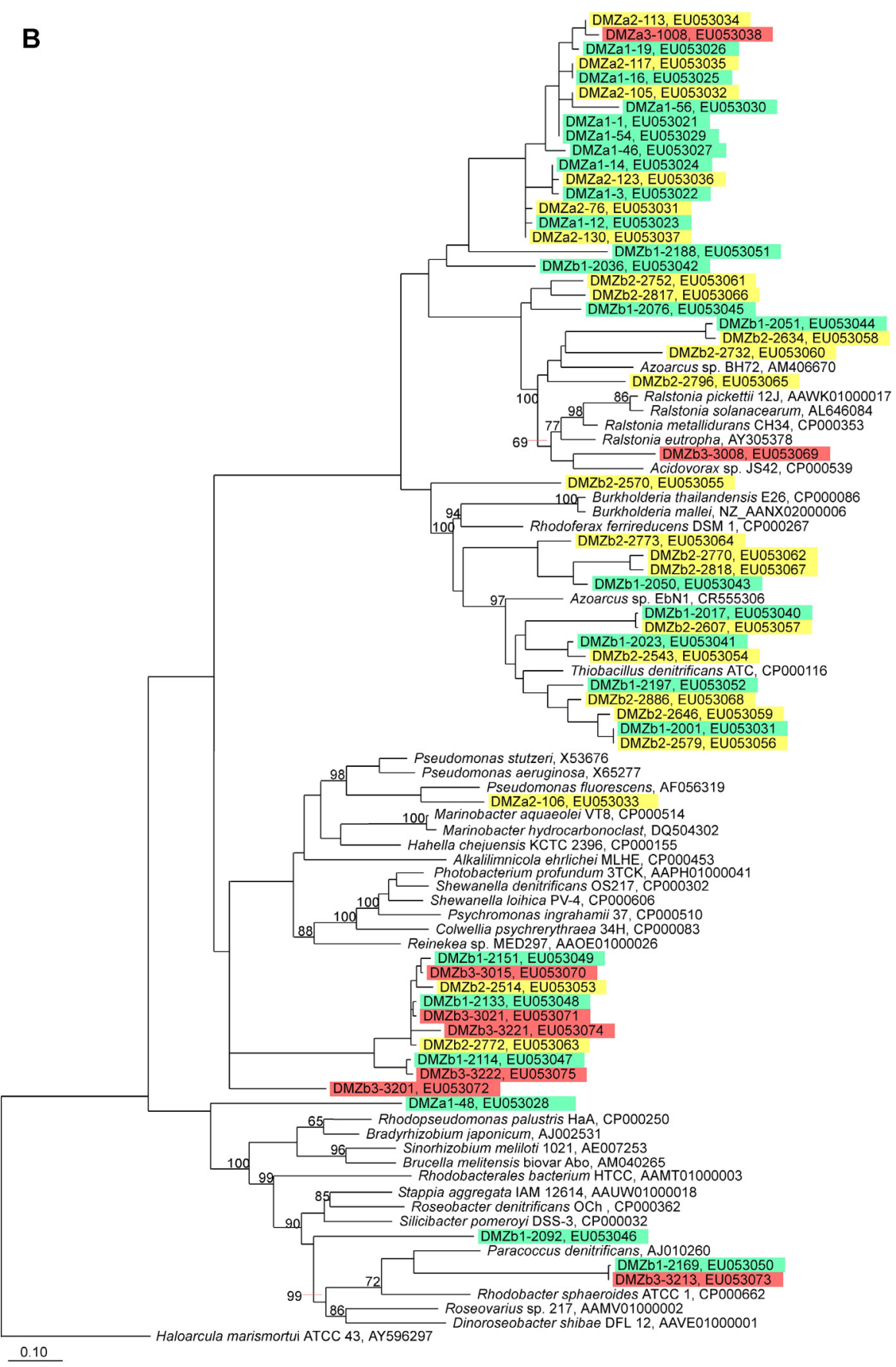

Fig. 3. (Continued)

difference in narG phylotype richness between sediment with and without $C$. plumosus larvae and also a higher phylotype richness of nosZ transcripts in the gut of the larvae. In contrast, a major difference in nos $Z$ phylotype richness between sediment with and without $C$. plumosus larvae would not be expected because of the similarly high coverage of the respective clone libraries (Table 2).

Putative mechanisms behind C. plumosus' effects on the nitrate reducer and denitrifier community

The observed shift in the community composition of nitrate reducers and denitrifiers may be explained in three ways: (1) habitat structuring, i.e., addition or removal of ecological niches by the larvae (e.g., by adding the distinct microenvironments of burrow and gut); (2) metabolic induction of bacteria in the gut followed by inoculation of the sediment with active bacteria; and (3) elimination of certain bacterial species via digestion in the gut. For a first indication of the mechanisms possibly at play, the diversity of narG and nos $Z$ phylotypes actively expressed in the gut of $C$. plumosus larvae was compared to the diversity of narG and nosZ phylotypes in sediments with and without larvae (Fig. 2). The total number of narG and nosZ phylotypes observed in the gut $(G)$, in sediment without larvae $\left(S_{0}\right)$, and sediment with larvae $\left(S_{1}\right)$ was 114 and 42 , respectively. Individual phylotypes could appear in either one, two, or three of the $G, S_{0}$, and $S_{1}$ libraries; the relative frequency of each possible phylotype distribution was expressed as a fraction of the total number of narG or nosZ phylotypes (Fig. 2). 
For nitrate-reducing bacteria, the quantitative assessment of putative mechanisms in Fig. 2 suggests that niche construction by the larvae was of greatest importance for the observed increase in phylotype richness (Table 2), since $45 \%$ of all narG phylotypes were only detected in sediment with larvae, not in sediment without larvae and not as transcripts in the gut either (Fig. 2, orange). Apparently, induction in the gut or elimination through digestion did not occur for these additional phylotypes. Only a small fraction of all narG phylotypes (5\%) contributed to the observed increase in phylotype richness through gut induction followed by sediment inoculation (Fig. 2, light blue). In a considerably larger fraction of all narG phylotypes, however, gut induction was not sufficient to inoculate the sediment with metabolically active nitrate reducers (Fig. 2, yellow and white). Elimination occurred for one fourth of all narG phylotypes (Fig. 2, white and dark blue). Higher coverages of the $S_{0}$ and $S_{1}$ libraries would probably not have rendered niche construction by the larvae a less important factor for increased phylotype richness. The role of gut induction, however, may have been underestimated due to the particularly low coverage of the $S_{1}$ library.

For nitrous-oxide-reducing bacteria, no difference in overall species richness was observed between sediments with and without $C$. plumosus (Table 2). Nevertheless, niche construction by the larvae was important, since $33 \%$ of all nosZ phylotypes were exclusively detected in sediment with larvae (Fig. 2, orange). In contrast, gut induction followed by sediment inoculation was not observed at all (Fig. 2, light blue). In fact, for a significant proportion of all nosZ phylotypes, gut induction occurred, but did not lead to sediment inoculation (Fig. 2, yellow and white). However, the extent of gut induction followed by sediment inoculation may have been underestimated due to the low coverage of the G library. Elimination of nos $Z$ phylotypes was of greater relative importance than observed for narG phylotypes and obviously prohibited an overall increase in nos $Z$ phylotype richness (Fig. 2, white and dark blue).

\section{Conclusion and perspective}

Our results indicate that the most important factor for increased denitrification, $\mathrm{N}_{2} \mathrm{O}$ emission, and nitrate reducer diversity, and for the change in denitrifier community composition is niche construction by C. plumosus larvae. Although a local increase in nitrate reducer and denitrifier abundance at the burrow walls (below the sensitivity of the qPCR assay) cannot be excluded, overall abundances do not change; therefore the increased rates are best explained by a higher sediment volume ideal for denitrification and hence a higher fraction of active denitrifiers, possibly together with higher cell-specific denitrification rates of the altered community. Finally it can be speculated that nitrate reducers can cope better with the dynamic conditions inside the $C$. plumosus burrow than complete denitrifiers because they only have to express one rather than four reductases during the recurring oxic-anoxic shifts inside the burrow. Hence, the burrow microenvironment may select for non-denitrifying nitrate reducers and against denitrifying nitrousoxide reducers.

\section{Funding}

This research was supported by a EU Marie Curie Fellowship to PS, by the Danish Research Agency (Grant 2117-05-0027 to AS), and by the Aarhus University, Denmark.

\section{Acknowledgements}

We thank B. Poulsen and P. Sørensen for excellent laboratory assistance. P. Deines is thanked for collection of $C$. plumosus larvae. K.U. Kjeldsen and M.B. Lund are acknowledged for generously helping with reconstruction of phylogenies.

\section{References}

[1] Aller, R.C., Yingst, J.Y.(1985) Effects of the marine deposit-feeders Heteromastus filiformis (Polychaeta), Macoma balthica (Bivalvia), and Tellina texana (Bivalvia) on averaged sedimentary solute transport, reaction rates, and microbial distributions. J. Mar. Res. 43, 615-645.

[2] Altmann, D., Stief, P., Amann, R., De Beer, D. (2004) Nitrification in freshwater sediments as influenced by insect larvae: quantification by microsensors and fluorescence in situ hybridization. Microb. Ecol. 48, 145-153.

[3] Bartoli, M., Nizzoli, D., Welsh, D.T., Viaroli, P. (2000) Short-term influence of recolonisation by the polychaete worm Nereis succinea on oxygen and nitrogen fluxes and denitrification: a microcosm study. Hydrobiologia 431, 165-174.

[4] Baumann, B., Snozzi, M., Zehnder, A.J.B., Van Meer, J.R.D. (1996) Dynamics of denitrification activity of Paracoccus denitrificans in continuous culture during aerobic-anaerobic changes. J. Bacteriol. 178, 4367-4374.

[5] Bergaust, L., Bakken, L.R., Frostegaard, A.H. (2011) Denitrification regulatory phenotype, a new term for the characterization of denitrifying bacteria. Biochem. Soc. Trans. 39, 207-212.

[6] Braker, G., Dörsch, P., Bakken, L. (2012) Genetic characterization of denitrifier communities with contrasting intrinsic functional traits. FEMS Microbiol. Ecol. 79, 542-554.

[7] Bremner, J.M. (1997) Sources of nitrous oxide in soils. Nutr. Cycl. Agroecosys. 49, 7-16.

[8] Chao, A. (1984) Nonparametric-estimation of the number of classes in a population. Scand. J. Stat. 11, 265-270.

[9] Chao, A., Lee, S.M. (1992) Estimating the number of classes via sample coverage. J. Am. Stat. Assoc. 87, 210-217.

[10] Codispoti, L.A. (2010) Interesting times for marine $\mathrm{N}_{2} \mathrm{O}$. Science 327 1339-1340.

[11] D‘Andrea, A.F., Dewitt, T.H. (2009) Geochemical ecosystem engineering by the mud shrimp Upogebia pugettensis (Crustacea: Thalassinidae) in Yaquina Bay, Oregon: density-dependent effects on organic matter remineralization and nutrient cycling. Limnol. Oceanogr. 54, 1911-1932.

[12] Dendooven, L., Anderson, J.M. (1994) Dynamics of reduction enzymes involved in the denitrification process in pasture soil. Soil Biol. Biochem. 26, 1501-1506.

[13] Foesel, B.U., Gieseke, A., Schwermer, C.U., Stief, P., Koch, L., Cytryn, E., de la Torré, J.R., van Rijn, J., Minz, D., Drake, H.L., Schramm, A. (2008) Nitrosomonas Nm143like ammonia oxidizers and Nitrospira marina-like nitrite oxidizers dominate the nitrifier community in a marine aquaculture biofilm. FEMS Microbiol. Ecol. 63, 192-204.

[14] Gilbert, F., Aller, R.C., Hulth, S. (2003) The influence of macrofaunal burrow spacing and diffusive scaling on sedimentary nitrification and denitrification: an experimental simulation and model approach. J. Mar. Res. 61, 101-125.

[15] Hannides, A.K., Dunn, S.M., Aller, R.C. (2005) Diffusion of organic and inorganic solutes through macrofaunal mucus secretions and tube linings in marine sediments. J. Mar. Res. 63, 957-981.

[16] Heisterkamp, I.M., Schramm, A., De Beer, D., Stief, P. (2010) Nitrous oxide production associated with coastal marine invertebrates. Mar. Ecol. Prog. Ser. 415 $1-9$.

[17] Heisterkamp, I.M., Schramm, A., Larsen, L.H., Svenningsen, N.B., Lavik, G., De Beer, D., Stief, P. (2013) Shell biofilm-associated nitrous oxide production in marine molluscs: processes, precursors, and relative importance. Environ. Microbiol. 15, 1943-1955.

[18] Henry, S., Bru, D., Stres, B., Hallet, S., Philippot, L. (2006) Quantitative detection of the nosZ gene, encoding nitrous oxide reductase, and comparison of the abundances of 16S rRNA, narG, nirK, and nosZ genes in soils. Appl. Environ. Microbiol. 72, 5181-5189.

[19] Ihssen, J., Horn, M.A., Matthies, C., Gossner, A., Schramm, A., Drake, H.L. (2003) $\mathrm{N}_{2} \mathrm{O}$-producing microorganisms in the gut of the earthworm Aporrectoded caliginosa are indicative of ingested soil bacteria. Appl. Environ. Microbiol. 69, 1655-1661.

[20] Johnson, R.K., Boström, B., van de Bund, W. (1989) Interactions between Chironomus plumosus (L.) and the microbial community in surficial sediments of a shallow, eutrophic lake. Limnol. Oceanogr. 34, 992-1003.

[21] Jones, C.M., Stres, B., Rosenquist, M., Hallin, S. (2008) Phylogenetic analysis of nitrite, nitric oxide, and nitrous oxide respiratory enzymes reveal a complex evolutionary history for denitrification. Mol. Biol. Evol. 25, 1955-1966.

[22] Jones, C.M., Welsh, A., Throbäck, I., Dörsch, P., Bakken, L., Hallin, S. (2011) Phenotypic and genotypic heterogeneity among closely related soil-borne $\mathrm{N}_{2}$ - and $\mathrm{N}_{2} \mathrm{O}$-producing Bacillus isolates harboring the nosZ gene. FEMS Microbiol. Ecol. $76,541-552$

[23] Kemp, P.F., Aller, J.Y. (2004) Estimating prokaryotic diversity: when are 16 S rDNA libraries large enough? Limnol. Oceanogr. Methods 2, 114-125.

[24] Kester, R.A., deBoer, W., Laanbroek, H.J. (1997) Production of NO and $\mathrm{N}_{2} \mathrm{O}$ by pure cultures of nitrifying and denitrifying bacteria during changes in aeration. Appl. Environ. Microbiol. 63, 3872-3877.

[25] Kofoed, M.V.W., Stief, P., Hauzmayer, S., Schramm, A., Herrmann, M. (2012) Higher nitrate-reducer diversity in macrophyte-colonized compared to unvegetated freshwater sediment. Syst. Appl. Microbiol. 35, 465-472. 
[26] Kristensen, E., Penha-Lopes, G., Delefosse, M., Valdemarsen, T., Quintana, C.O., Banta, G.T. (2012) What is bioturbation? The need for a precise definition for fauna in aquatic sciences. Mar. Ecol. Prog. Ser. 446, 285-302.

[27] Lagauzère, S., Boyer, P., Stora, G., Bonzom, J.M. (2009) Effects of uraniumcontaminated sediments on the bioturbation activity of Chironomus riparius larvae (Insecta, Diptera) and Tubifex tubifex worms (Annelida, Tubificidae). Chemosphere 76, 324-334.

[28] Leuchs, H., Neumann, D. (1990) Tube texture, spinning and feeding behaviour of Chironomus larvae. Zool. Jb. Syst. 117, 31-40.

[29] Lucas, F.S., Bertru, G., Höfle, M.G. (2003) Characterization of free-living and attached bacteria in sediments colonized by Hediste diversicolor. Aquat. Microb. Ecol. 32, 165-174

[30] Ludwig, W., Strunk, O., Westram, R., Richter, L., Meier, H., Yadhukumar, A., Buchner, T., Lai, S., Steppi, G., Jobb, W., Forster, I., Brettske, S., Gerber, A.W., Ginhart, O., Gross, S., Grumann, S., Hermann, R., Jost, A., Konig, T., Liss, R., Lussmann, M., May, B., Nonhoff, B., Reichel, R., Strehlow, A., Stamatakis, N., Stuckmann, A., Vilbig, M., Lenke, T., Ludwig, A., Bode, K.-H., Schleifer, (2004) ARB: a software environment for sequence data. Nucleic Acids Res. 32, $1363-1371$.

[31] Mullins, T.D., Britschgi, T.B., Krest, R.L., Giovannoni, S.J. (1995) Genetic comparisons reveal the same unknown bacterial lineages in Atlantic and Pacific bacterioplankton communities. Limnol. Oceanogr. 40, 148-158.

[32] Nogaro, G., Mermillod-Blondin, F., Montuelle, B., Boisson, J.C., Gibert, J. (2008) Chironomid larvae stimulate biogeochemical and microbial processes in a riverbed covered with fine sediment. Aquat. Sci. 70, 156-168.

[33] Papaspyrou, S., Gregersen, T., Cox, R.P., Thessalou-Legaki, M., Kristensen, E. (2005) Sediment properties and bacterial community in burrows of the ghost shrimp Pestarella tyrrhena (Decapoda: Thalassinidea). Aquat. Microb. Ecol. 38, $181-190$.

[34] Pelegri, S.P., Blackburn, T.H. (1994) Bioturbation effects of the amphipod Corophium volutator on microbial nitrogen transformations in marine sediments. Mar. Biol. 121, 253-258.

[35] Pelegri, S.P., Blackburn, T.H. (1996) Nitrogen cycling in lake sediments bioturbated by Chironomus plumosus larvae, under different degrees of oxygenation. Hydrobiologia 325, 231-238.

[36] Plante, C.J., Shriver, A.G. (1998) Differential lysis of sedimentary bacteria by Arenicola marina L.: Examination of cell structure exopolymeric capsules as correlates. J. Exp. Mar. Biol. Ecol. 229, 35-52.

[37] Plante, C.J., Wilde, S.B. (2001) Bacterial recolonization of deposit-feeder egesta: In situ regrowth or immigration? Limnol Oceanogr. 46, 1171-1181.

[38] Polerecky, L., Volkenborn, N., Stief, P. (2006) High temporal resolution oxygen imaging in bioirrigated sediments. Environ. Sci. Technol. 40, 5763-5769.

[39] Riisgard, H.U., Larsen, P.S. (2005) Water pumping and analysis of flow in burrowing zoobenthos: an overview. Aquat. Ecol. 39, 237-258.

[40] Roskosch, A., Morad, M.R., Khalili, A., Lewandowski, J. (2010) Bioirrigation by Chironomus plumosus: advective flow investigated by particle image velocimetry. J. N. Am. Benthol. Soc. 29, 789-802.

[41] Scala, D.J., Kerkhof, L.J. (1998) Nitrous oxide reductase (nosZ) gene-specific PCR primers for detection of denitrifiers and three nosZ genes from marine sediments. FEMS Microbiol. Lett. 162, 61-68.
[42] Schloss, P.D., Handelsman, J. (2005) Introducing DOTUR, a computer program for defining operational taxonomic units and estimating species richness. Appl. Environ. Microbiol. 71, 1501-1506.

[43] Schreiber, F., Loeffler, B., Polerecky, L., Kuypers, M.M.M., De Beer, D. (2009) Mechanisms of transient nitric oxide and nitrous oxide production in a complex biofilm. ISME J. 3, 1301-1313.

[44] Sørensen, J. (1978) Occurrence of nitric and nitrous oxides in a coastal marine sediment. Appl. Environ. Microbiol. 36, 809-813.

[45] Smith, C.J., Nedwell, D.B., Dong, L.F., Osborn, A.M. (2007) Diversity and abundance of nitrate reductase genes (narG and $\operatorname{napA}$ ), nitrite reductase genes (nirS and $n r f A$ ), and their transcripts in estuarine sediments. Appl. Environ. Microbiol. 73, 3612-3622.

[46] Stief, P., De Beer, D. (2006) Probing the microenvironment of freshwater sediment macrofauna: implications of deposit-feeding and bioirrigation for nitrogen cycling. Limnol. Oceanogr. 51, 2538-2548.

[47] Stief, P., Eller, G. (2006) The gut microenvironment of sediment-dwelling Chironomus plumosus larvae as characterised with $\mathrm{O}_{2}, \mathrm{pH}$, and redox microsensors. J. Comp. Physiol. B 176, 673-683.

[48] Stief, P. (2007) Enhanced exoenzyme activities in sediments in the presence of deposit-feeding Chironomus riparius larvae. Freshwat. Biol. 52, 1807-1819.

[49] Stief, P., Poulsen, M., Nielsen, L.P., Brix, H., Schramm, A. (2009) Nitrous oxide emission by aquatic macrofauna. Proc. Natl. Acad. Sci. U.S.A. 106, 4296-4300.

[50] Stief, P., Polerecky, L., Poulsen, M., Schramm, A. (2010) Control of nitrous oxide emission from Chironomus plumosus larvae by nitrate and temperature. Limnol. Oceanogr. 55, 872-884.

[51] Stief, P., Schramm, A. (2010) Regulation of nitrous oxide emission associated with benthic invertebrates. Freshwat. Biol. 55, 1647-1657.

[52] Svenningsen, N.B., Heisterkamp, I.M., Sigby-Clausen, M., Larsen, L.H., Nielsen, L.P., Stief, P., Schramm, A. (2012) Shell biofilm nitrification and gut denitrification contribute to emission of nitrous oxide by the invasive freshwater mussel Dreissena polymorpha (zebra mussel). Appl. Environ. Microbiol. 78, 4505-4509.

[53] Svensson, J.M. (1997) Influence of Chironomus plumosus larvae on ammonium flux and denitrification (measured by the acetylene blockage- and the isotope pairing-technique) in eutrophic lake sediment. Hydrobiologia 346, 157-168.

[54] Svensson, J.M. (1998) Emission of $\mathrm{N}_{2} \mathrm{O}$, nitrification and denitrification in a eutrophic lake sediment bioturbated by Chironomus plumosus. Aquat. Microb. Ecol. 14, 289-299.

[55] Svensson, J.M., Enrich-Prast, A., Leonardson, L. (2001) Nitrification and denitrification in a eutrophic lake sediment bioturbated by oligochaetes. Aquat. Microb. Ecol. 23, 177-186.

[56] Tiedje, J.M. (1988) Ecology of denitrification and dissimilatory nitrate reduction to ammonium. In: Zehnder, A.J.B. (Ed.), Biology of Anaerobic Microorganisms, Wiley, New York, pp. 179-244.

[57] Walshe, B.M. (1947) Feeding mechanisms of Chironomus larvae. Nature. 160, 474.

[58] Yeager, P.E., Foreman, C.L., Sinsabaugh, R.L. (2001) Microbial community structure and function in response to larval chironomid feeding pressure in a microcosm experiment. Hydrobiologia 448, 71-81.

[59] Zumft, W.G. (1997) Cell biology and molecular basis of denitrification. Microbiol. Mol. Biol. Rev. 61, 533-616. 